\title{
GCC Fiscal Reforms and Labor Market Policies
}

\author{
Monica Malik and Thirumalai Nagesh
}

\section{INTRODUCTION}

The social contract between the government and the population in GCC countries is central to the issues of fiscal reform and adjustment to the lower oil price, as we highlighted in our earlier chapter. The social contract is based on a framework of distribution of hydrocarbon earning and wealth to the national population, including areas, such as employment, healthcare, education, housing and subsidized fuel and utilities. A significant fiscal reform program, both on the revenue and expenditure sides, will result in a re-defining of this contract. The ability to continue to provide the same degree of support by GCC governments to the national population is both impacted by the fall in hydrocarbon prices from end-2014 and the strong population growth over the last few decades. However, as noted earlier, there are marked variations on the ability to support the national population based on hydrocarbon endowment per capita.

M. Malik $(\bowtie) \bullet$ T. Nagesh

The Hills Compound, Abu Dhabi, United Arab Emirates

e-mail: monica.malik@adcb.com; Thirumalainagesh.Venkatesh@adcb.com

(C) The Author(s) 2021

G. Luciani, T. Moerenhout (eds.), When Can Oil Economies Be

Deemed Sustainable?, The Political Economy of the Middle East, https://doi.org/10.1007/978-981-15-5728-6_10 
One of the main pillars of the social contract is the role of the public sector in the employment of nationals, whilst conversely, the private sector has benefited by the ability to employ cheaper expatriate labor. Historically, with the rise in oil revenue, particularly from the 1970s, though also earlier, the influx of expatriate labor has been central for the quick transformation of the economy and the development of infrastructure. The IMF noted that productivity growth in the region has been unsatisfactory, and the strong economic expansion has been fuelled by low-cost foreign labor. This expatriate labor force has also been highly flexible and elastic, adjusting to economic growth cycles. Meanwhile, the public sector employment of nationals was central to the quick rise in the living standard, alongside the deployment of wider social distribution. The IMF noted that for the Middle East Region "countries in the region have used public employment and compensation policies to achieve multiple socioeconomic objectives, including employment and redistribution of wealth" (IMF 2018,9). Public sector employment has generally been better paid than the private sector, with the tendency for jobs for life, generous pension schemes and perks, such as greater holiday benefits (Figs. 10.1 and 10.2).

\section{$\%$ change}

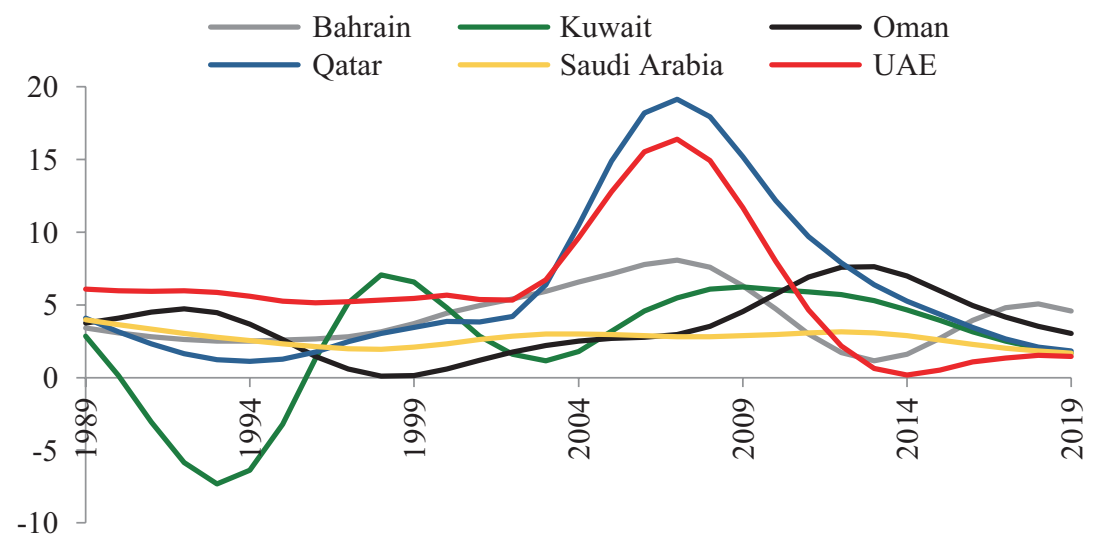

Fig. 10.1 GCC: Total population growth reflects economic cycles and the flexibility of foreign labor. (Source: United Nations) 
Numbers employed '000 (LHA); \% change (RHA)

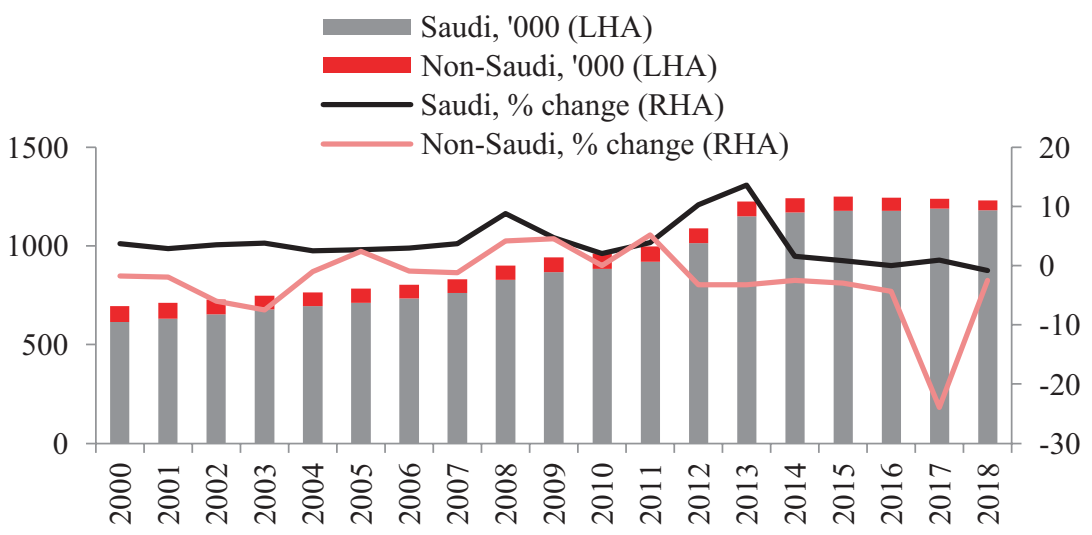

Fig. 10.2 Saudi Arabia: Employment dynamics in the public sector. (Source: SAMA)

With the lower oil price in the 1990s, GCC governments increasingly turned policy discussion towards diversification of the economic base and private sector development, in part to create job opportunities for nationals outside the public sector. Moreover, there were a number of initiatives to raise private sector employment directly, such as labor nationalization programs, and indirectly, educational reforms. However, the preference to work in the public sector remained, and with the sharp increase in the oil price in the 2000s, government hiring and spending on wages rose. Again, the region saw strong expatriate population growth as the higher oil revenue supported an upgrading of infrastructure, alongside wider spending. The IMF noted that the rise in the public sector wage bill was attributable to both increase in government employment and high public sector wages (IMF 2014, 13). Furthermore, the IMF highlighted that GCC governments' public sector wage bills are considerably larger than in other oilexporting countries. Since 2014, the emphasis on private sector developments and diversification has reemerged and is being stressed, though it had remained a central tenet of medium-term development objectives (Figs. 10.3 and 10.4).

The need to create jobs for the youth population and, in some cases, to reduce the current levels of national unemployment remains one of the key focuses of domestic policy and arguably the greatest economic 
\% of total workforce in 2018

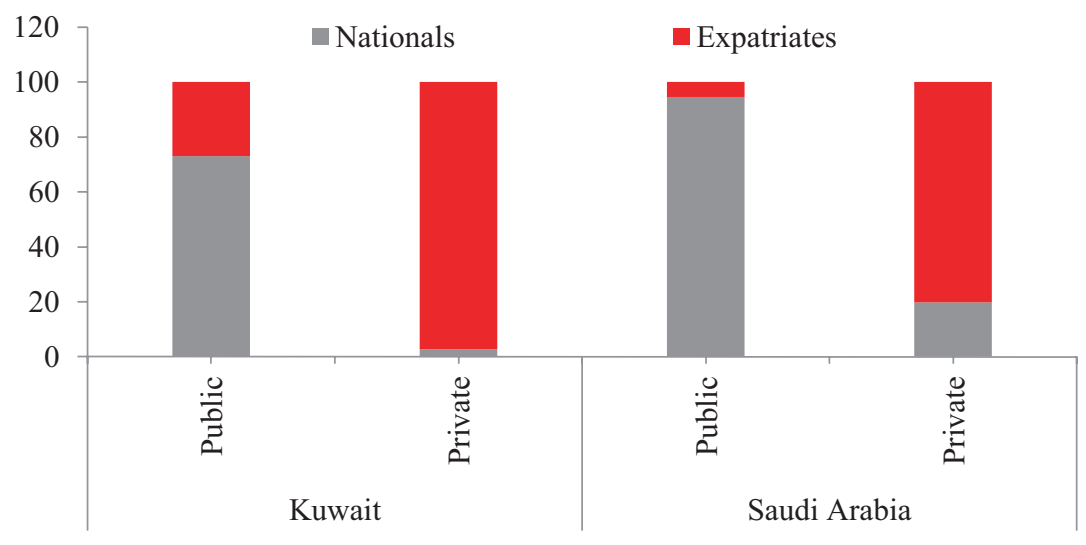

Fig. 10.3 Saudi Arabia and Kuwait: Significant variations in composition of public and private sector labor force. (Source: PACI, Saudi Arabia General Authority of Statistics)

\section{Million, 2020 projections}

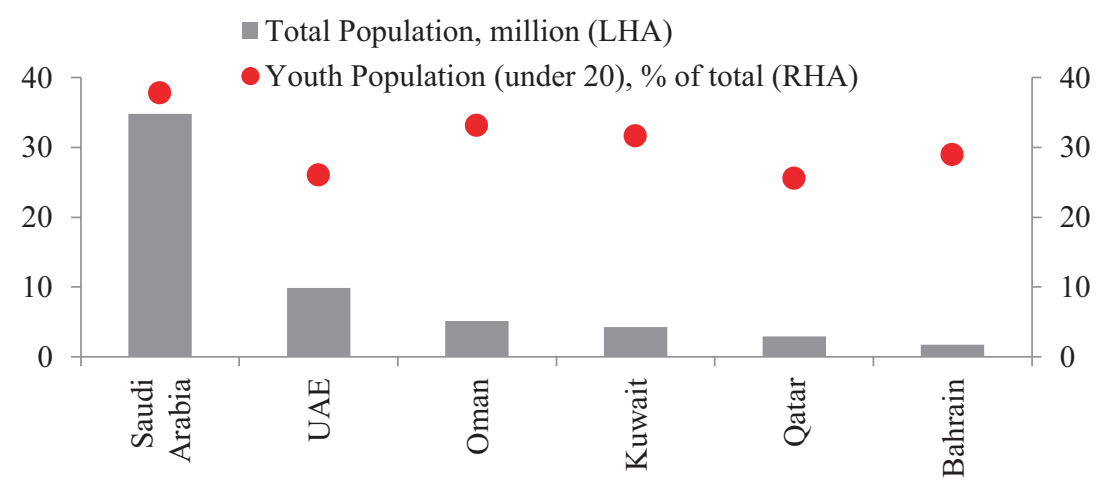

Fig. 10.4 GCC: Large youth population requires strong job creation. (Source: United Nations) 
challenge. We had argued in one of our earlier research reports on the Vision 2030 plan that "Ultimately, creating jobs for younger people and diversifying the economy will be the key litmus test to determine whether or not the transformation process has been successful" (ADCB 2017b, 3). Youth unemployment is already high in some countries, notably in Saudi Arabia and Oman, which are both relatively hydrocarbon poorer per capita countries with less diversified economies. The World Bank noted that "The main social concern for Oman is the lack of jobs and the adverse effects of subsidy reform on vulnerable households (World Bank 2018). Indeed, the greater social pressures in these two countries are reflected in their recent labor and fiscal policies. The national unemployment rate in the hydrocarbon richer per capita countries is lower, with a relatively small population which can more easily be absorbed by the public sector. Nevertheless, the young demographic profile across the region points to the need for strong job creation over the next five to ten years.

In this chapter, we develop the themes from our previous one-on hydrocarbon endowment per capita and fiscal reform-focusing on the context of population dynamics and the labor market. We note that the fiscal reform program this time has impacted the national population, making it significant and broader than the previous rounds. Nevertheless, any changes in the social contract were always going to be gradual and take time to redefine. There have been instances of measures introduced to mitigate the impact of the reforms on the domestic population and reduce short-term social pressures. Alongside the fiscal reforms, a number of labor reforms have also been introduced to support job creation in the private sector for nationals. With the rise in oil price from 2017, there have also been some tentative signs of greater hiring by the government, alongside raising support in other areas, such as housing (Figs. 10.5 and 10.6).

\section{National Population Impacted by Reforms; Greatest Burden on Expatriates}

The broader nature of the fiscal adjustment has meant that the national population has been directly affected, making this reform cycle notable, especially compared to the previous one. The national population has been impacted by measures, such as the higher prices linked to the reductions in subsidies (fuel and utilities), the introduction of VAT and the excise tax. The fact that fiscal reforms have included areas that were 


\section{Million, 2020 projections}

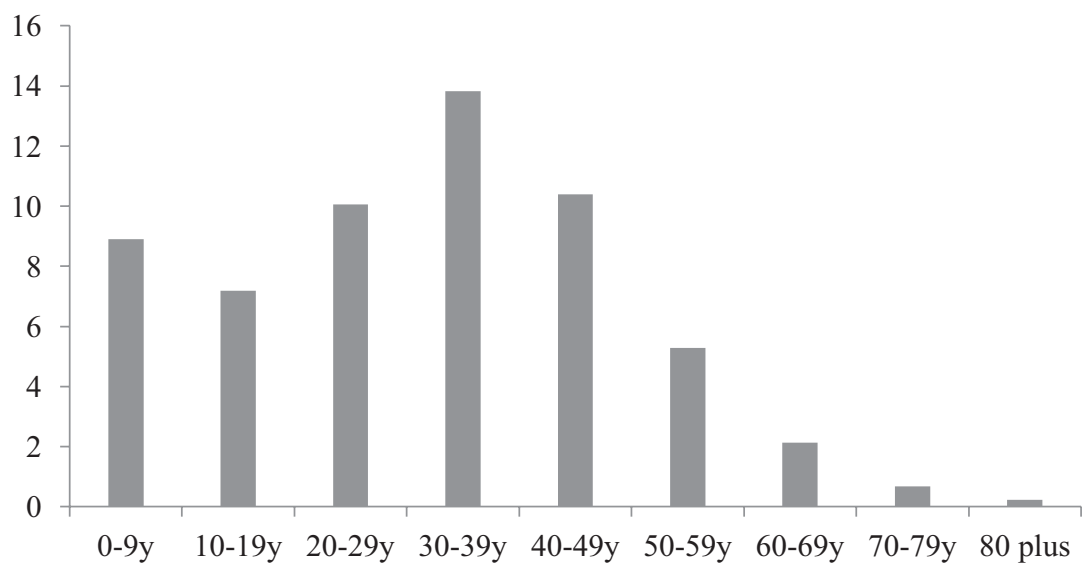

Fig. 10.5 GCC: Demographic profile of GCC population dominated by young and working age population. (Source: United Nations Population Division)

USD per capita in 2018

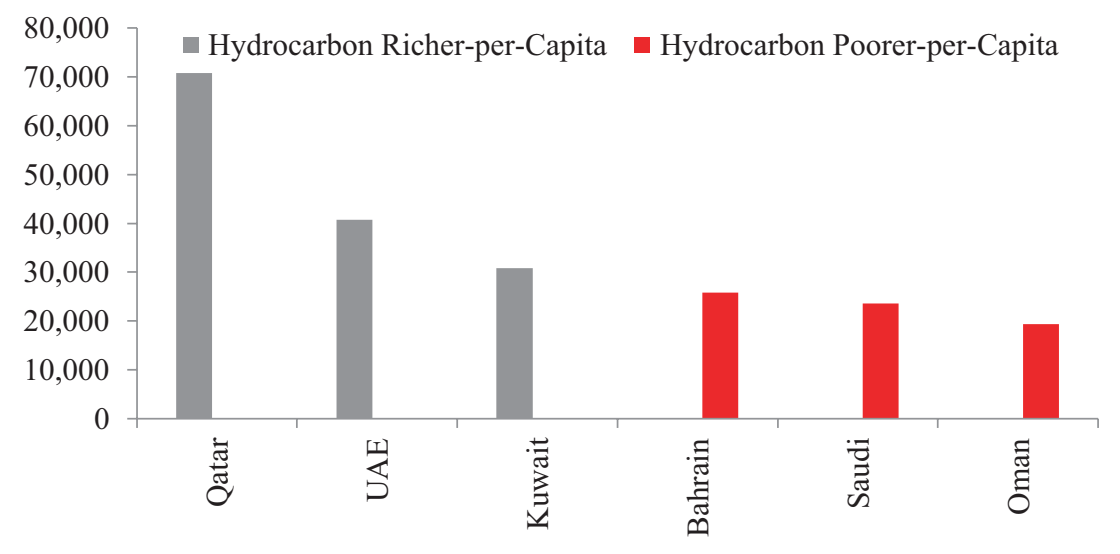

Fig. 10.6 GCC: UAE and Qatar have higher GDP per capita among the GCC countries. (Source: IMF, WEO April 2019) 
previously seen as being too sensitive to change or tackle is a significant step, even though the social contract remains in place. This potentially opens the door for deeper and wider fiscal reforms going forward in the medium- to longer-term. Nevertheless, overall a greater burden of the fiscal reforms has fallen on the expatriate population and in some cases corporates, with the national population relatively more shielded, especially from 2017. With the corporate sector impacted by fiscal reform, it raises questions over the short-term ability of the private sector to drive real GDP growth and support the diversification of the economy. In some cases, the private sector has faced additional pressure due to labor market reforms. The development of a framework to boost private sector activity, including through PPP schemes, remains vital.

The trend to target more of the reform burden at expatriates was seen in a number of instances in the region, including in the last two rounds of utility subsidy reductions in Abu Dhabi. In January 2016, utility prices were increased just for higher-consumption expatriates. In January 2017, prices were raised for both expatriates and nationals, alongside corporate and government entities, though with the cost markedly higher for expatriates than nationals in absolute terms. According to the official statement announcing the January 2017 utility price changes, the amended tariffs reflect the actual cost of supplying water and electricity to all categories of customers. This implies that prices have been largely liberalized (Table 10.1). In Kuwait, utility reforms of August 2017 targeted corporates, government entities and the investment sector. The investment sector includes real estate, and thus the higher prices affect the majority of expatriates who rent properties. When presenting the draft budget for FY2018-2019, the Kuwaiti minister of finance noted that the main reform "starts with curbing spending, while maintaining a healthy rate of capital expenditure on infrastructure and minimizing the impact of our fiscal reforms on citizens".

As mentioned in our previous chapter, the Saudi government moved to reduce the impact of price increases on nationals following the rise in utility and fuel prices and the introduction of VAT on l January 2018. A package of hand-outs for public sector employees was announced within one week of the 1 January price increases and came after signs of disappointment with the latest austerity measures and after the cash handouts from the Citizens Account introduced at end-December 2017 fell short of covering rising living expenses. The Citizens Account is a means-tested cash-transfer program to support low- to middle-income households from 
Table 10.1 Abu Dhabi: Water and electricity tariffs for households

\begin{tabular}{|c|c|c|c|c|}
\hline & $\begin{array}{l}\text { Pre } \\
\text { Jan-2015 }\end{array}$ & Jan-15 & Jan-16 & $\operatorname{Jan}-17^{a}$ \\
\hline \multicolumn{5}{|l|}{ Nationals } \\
\hline $\begin{array}{l}\text { Power usage below } 30 \mathrm{KwH} / \text { day } \\
\text { for apartments and } 400 \mathrm{KwH} / \text { day } \\
\text { for villas }\end{array}$ & $\begin{array}{l}5 \text { fils/ } \\
\mathrm{kWh}\end{array}$ & & & $\begin{array}{l}6.7 \text { fils / } \\
\text { kWh }\end{array}$ \\
\hline $\begin{array}{l}\text { Power usage above } 30 \mathrm{KwH} / \text { day for } \\
\text { apartments and } 400 \mathrm{KwH} / \text { day for } \\
\text { villas }\end{array}$ & $\begin{array}{l}5 \text { fils/ } \\
\mathrm{kWh}\end{array}$ & $\begin{array}{l}5.5 \text { fils } \\
\mathrm{kWh}\end{array}$ & & $\begin{array}{l}7.5 \text { fils } \\
\text { kWh }\end{array}$ \\
\hline $\begin{array}{l}\text { Water usage below } 700 \text { liters/day in } \\
\text { apartments and } 7000 \text { liters in villas }\end{array}$ & AED0 & AED1.7 & & AED2.09 \\
\hline $\begin{array}{l}\text { Water usage above } 700 \text { liters/day in } \\
\text { apartments and } 7000 \text { liters in villas } \\
\text { Expatriates }\end{array}$ & AED0 & AED1.89 & & AED2.6 \\
\hline Power consumption below & 15 fils/ & 21 fils $/ \mathrm{kWh}$ & & 26.8 fils/ \\
\hline $\begin{array}{l}20 \mathrm{KwH} / \text { day in apartments and up } \\
\text { to } 200 \mathrm{KwH} / \text { day in villas }\end{array}$ & $\mathrm{kWh}$ & & & $\mathrm{kWh}$ \\
\hline Power consumption above & 15 fils/ & Not & 31.8 fils/ & 30.5 fils/ \\
\hline $\begin{array}{l}20 \mathrm{KwH} / \text { day in apartments and up } \\
\text { to } 200 \mathrm{KwH} / \text { day in villas }\end{array}$ & $\mathrm{kWh}$ & announced & $\mathrm{kWh}$ & $\mathrm{kWh}$ \\
\hline $\begin{array}{l}\text { Water usage below } 700 \text { liters/day in } \\
\text { apartments and } 5000 \text { liters in villas }\end{array}$ & AED2.2 & AED5.95 & & AED7.84 \\
\hline $\begin{array}{l}\text { Water usage above } 700 \text { liters/day in } \\
\text { apartments and } 5000 \text { liters in villas }\end{array}$ & AED2.3 & AED9.9 & AED10.55 & AED10.41 \\
\hline
\end{tabular}

Source: Reuters, various media sources, cited from ADCB (2017a, 11)

aPrice increases effective 1 January 2017

the negative consequences of fiscal reform. The first payment was on 21 December 2017 ahead of the introduction of VAT and the second round of subsidy reforms. The swift response by the government in announcing the handout package is particularly notable given the wider reforms (including social), alongside developments, such as the anti-corruption drive in November 2017. We argued in our earlier research that economic reforms "are creating and redefining the economic, social, cultural and political structures in the Kingdom, as well as their relationships to each other" (ADCB 2017b, 2). As such, the government was quick to announce a package of support measures to reduce the impact of fiscal reforms for some nationals (particularly in the public sector) at a time of significant social, economic and political change. ADCB estimated that c.70\% of Saudi households likely benefited from the government allowance 
packages in 2018, with c.45\% likely seeing higher net income from the Citizen Account program (low-income Saudi households) (ADCB 2018, 1). Thus, expatriate households will be the most impacted by the reforms, especially when considering the levy on dependents from mid-2017 (see below). Notably, the public sector handout package for citizens (introduced in January 2018) was extended for 2019, alongside annual public sector bonuses for all state employees from the start of 2019.

In Oman, the government announced mitigation measures to support the vulnerable population in 2018. These included i) allocating OMR100 million (USD260 million) to support vulnerable households, ii) a new fuel subsidy scheme where households with an income below OMR600 will receive 200 liters of petrol per month at a subsidized rate (World Bank 2018). As highlighted in our earlier chapter, Oman has seen relatively limited fiscal reforms in this cycle, which perhaps reflects the greater social pressures linked to high unemployment rate, especially amongst the youth. Oman has focused on progressing with projects, in part to create jobs, alongside maximize revenue from each barrel of oil and raising gas output. Outside the hydrocarbon and petrochemical side, key areas of investment include logistics (ports, airports, etc.), tourism, utilities for industrial needs and other related infrastructure (road and rail). Foreign investment has been vital for supporting the investment drive, whilst also relying on raising debt and drawing down FX reserves to help cover the fiscal deficit. Out of the GCC countries, Oman has made the most progress with broadening the economic base since 2014. Bahrain also has made limited progress until 2019. These additional fiscal support packages, announced for public sector employees, reinforce the preference for nationals to work for government entities. Support measures have also been seen in other areas of the GCC. However, the UAE unified holiday between the private and public sectors in March 2019, with the aim of enhancing the attractiveness of the private sector for Emiratis.

\section{Hydrocarbon Endowment Per Capita AND THE LABOR MARKET}

Alongside the fiscal reforms, a number of policy measures have been introduced targeting the labor market to increase job opportunities for nationals in the private sector. Private sector job creation will be vital for (1) reducing social pressure, $(2)$ the number of jobs required to be created by 
the public sector and (3) the ability to introduce further subsidy and tax reforms going forward. Some countries have introduced or widened policies that target reducing the size of the foreign workforce, with the aim that these jobs will be replaced by nationals. The success of the programs has varied, though they have not addressed underlying factors, such as the cost of labor and skills mismatches. Within the GCC, the labor market pressures differ greatly, again reflecting the differences in hydrocarbon endowment per capita. The lower share of government spending on wage growth in the UAE and Qatar relative to other GCC countries (Figs. 10.7 and 10.8) reflects the ability for the government to absorb the domestic labor force and support spending in wider areas, bolstering nonhydrocarbon economic activity. Reflecting this, expatriates make up a greater proportion of total population in hydrocarbon richer per capita countries versus the relatively poorer per capita ones. In the case of the UAE, the more diversified economic base also lowers reliance on government jobs. In the case of Bahrain, the relatively more diversified economic backdrop supports the greater share of foreign employment in the labor force, versus Saudi and Oman. Kuwait stands out amongst the countries with higher hydrocarbon endowment per capita. We believe that the relatively high share of government spending to the total likely mirrors (1) the preference and ability of the government to employ nationals, (2)

Government wage bill, \% of GDP (2005-2016)

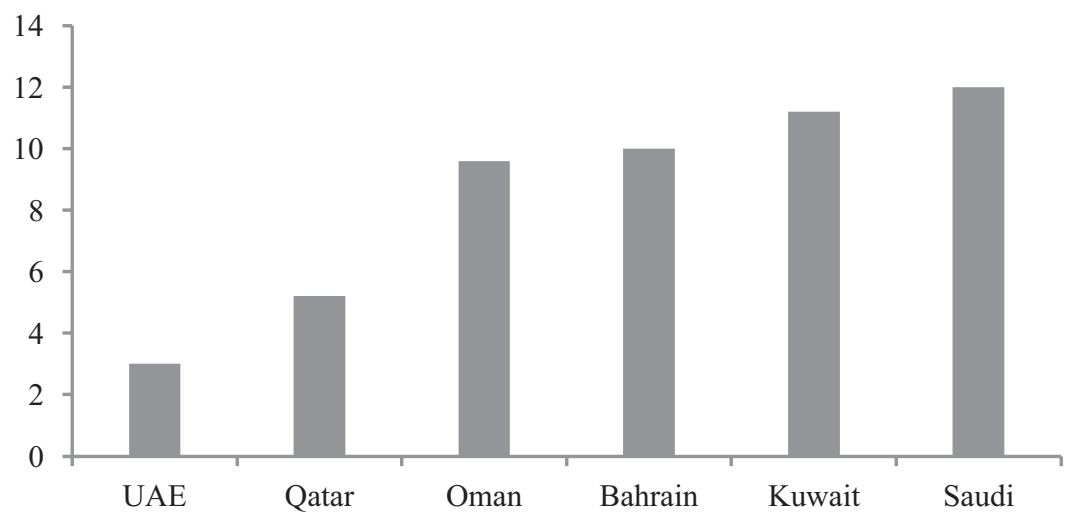

Fig. 10.7 GCC: Government spending on wages high in the region, though lower in the UAE and Qatar. (Source: IMF $(2018,9)$ ) 
\% of total population, data between 2016 and 2018

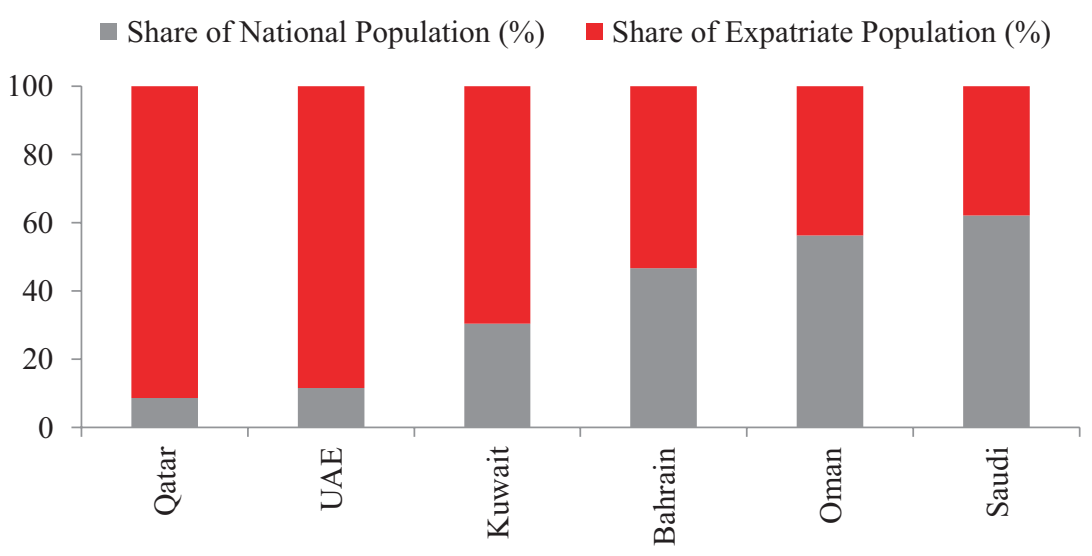

Fig. 10.8 GCC: Hydrocarbon richer per capita countries tend to have larger expatriate population in relative share. (Source: Calculated from regional statistics agencies and World Bank for UAE data)

relatively limited progress with the government investment program and (3) a less diversified economy. Government subsidies, handouts and public sector wages in Kuwait are some of the most generous in the region.

All GCC countries already had employment nationalization program to some degrees. The hydrocarbon richer per capital countries generally have lower employment targets and quotas for nationals in the private sector. The need for job creation among nationals remains high in the hydrocarbon poorer per capita countries, with the public sector unable to absorb all job seekers. Saudi Arabia and Oman have particularly focused on policies to replacing foreign labor with national in this round of reforms, in line with their challenging employment positions, and particularity from 2017 (Table 10.2).

The latest data for Saudi Arabia show that the unemployment rate for nationals stood at $12.5 \%$ in 1 Q2019 (male at $6.6 \%$ and female at $31.7 \%$ ), up from $11.5 \%$ in $4 \mathrm{Q} 2015$. The youth unemployment rate is significantly higher, at $36.3 \%$ in 1Q2019 for the 20-24 age range (ADCB 2019, 1). Going forward, Saudi Arabia could face added demand for jobs from greater female participation, which stood at around 20.5\% in 1Q2019. The Saudi government has introduced a number of measures to support 


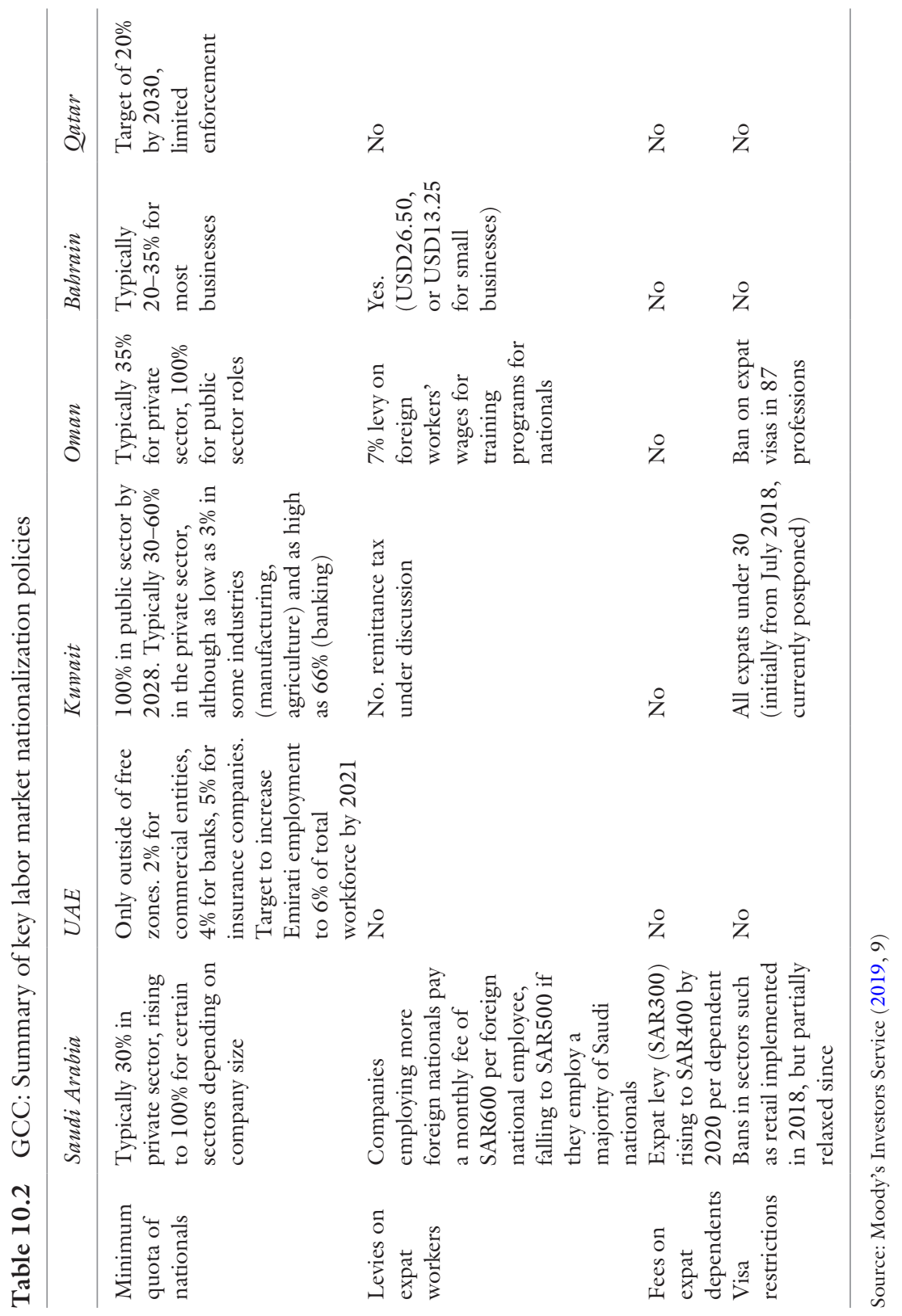


female employment, including setting quotas for certain sectors, as well as introducing childcare programs. In Oman, the World Bank (citing ILO data) indicated that unemployment "was $17 \%$ in 2017 , while youth unemployment is approximately $49 \%$ - a pressing challenge in Oman where over $40 \%$ of the population is under the age of 25 " (Figs. 10.9 and 10.10).

\section{Labor Market Reforms and Policies to Reduce FOREIGN LABOR}

Below we highlight some of the main labor market reforms introduced in this economic cycle. There are also some signs of greater public sector hiring in Saudi Arabia, potentially reflecting the fact that the private sector is not generating sufficient jobs to reduce current unemployment levels meaningfully. It could also reflect the hiring by institution driving the transformation program such as the PIF, alongside the development of new institutions around key diversification projects. The number of Saudis employed in the civil services was, however, lower than in 1Q2016 by some $4.2 \mathrm{~K}$-though insufficient to reduce the government wage bill, especially when considering the pay increases. Meanwhile, regarding the

Average SAR per month, 1Q2019

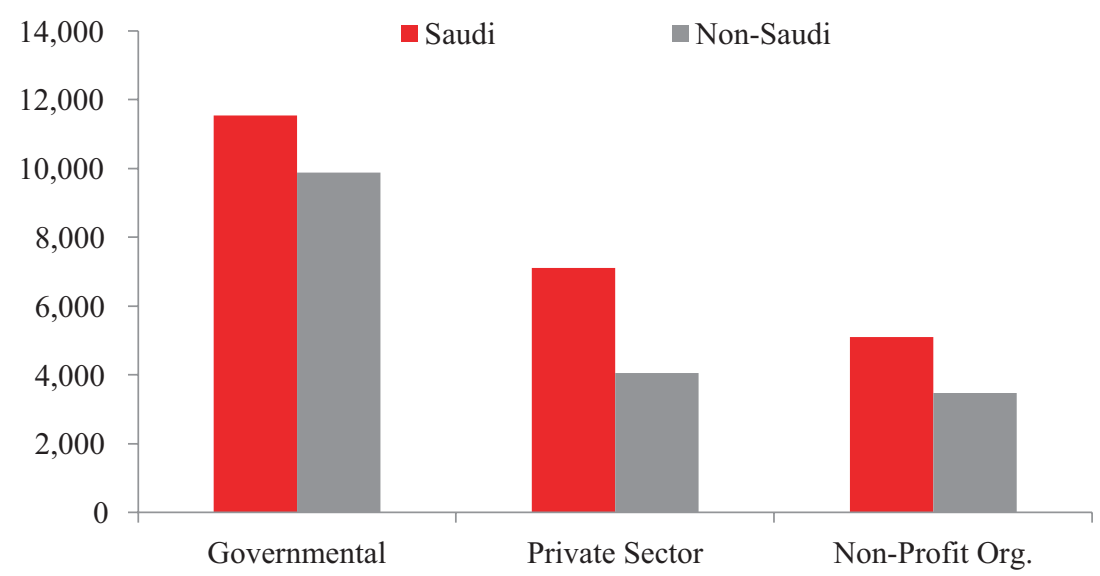

Fig. 10.9 Saudi Arabia; Higher wages and benefits in the public sector support demand for government jobs. (Source: Saudi Arabia General Authority for Statistics) 
$\%$ unemployment

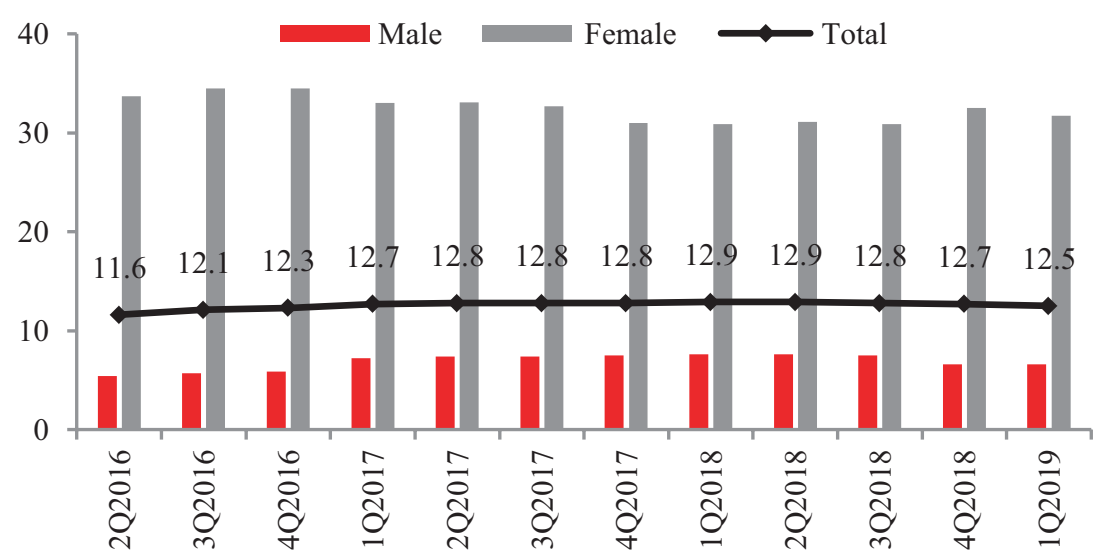

Fig. 10.10 Saudi Arabia: Unemployment rate amongst Saudi nationals remains high, especially females. (Source: Saudi Arabia General Authority for Statistics)

hydrocarbon richer per capita countries, Kuwait has seen the most populist pressure to reduce foreign employment levels, despite the low unemployment level and generous public sector packages, even on a GCC basis.

Saudi Arabia: The government has increased the number of sectors that require $100 \%$ Saudiization, particularly in the retail sector. This started with $100 \%$ Saudiization in mobile phones retail shops in September 2016, followed by car rental companies in March 2018. Also, in early 2018, Saudi Arabia's Ministry of Labor issued a decree to implement 100\% Saudiization in 12 new, mostly retail areas, including those concerned with watches, eyewear, medical equipment, electrical and electronic appliances, auto parts, building materials, carpets, cars and motorcycles, home and office furniture, children's clothing and men's accessories, home kitchenware and confectionery. Implementation started at end-September 2018 in three phases (to end by January 2019 ) though the Saudiization target was scaled down to $70 \%$, from the $100 \%$ initially outlined (Albawaba 2018). Notably, the move to nationalize jobs in areas such as retail indicates that Saudis are accepting nonmanagerial positions, which perhaps would not have been the case in previous decades. 
Saudi Arabia also announced its decision to Saudiize management and specialist professions in the tourism hospitality sector in July 2019. The implementation will come into effect starting 28 December 2019 for operating and specialized jobs, 22 June 2020 for supervisors and assistant managers, and 16 December 2020 for managers. The decision includes hotels classified as 3-star and above, resorts, hotel suites, and villas classified as 4 -star and above. Jobs in booking, marketing and front offices will be $100 \%$ Saudiized, whilst $70 \%$ will be required for sales managers and events and conferences sales managers. Tourism and hospitality are expected to be key sectors of jobs creation, going forward with a number of developments planned (NEOM, Red Sea, Al-Ula, Amaala, etc.). These Saudiization measures are likely aimed at ensuring that a significant part of new jobs being created as this sector develops go to nationals.

Moreover, the Saudi government has also raised fees and levies on foreign labor aimed at achieving two policy goals: (1) raising more non-oil revenue and (2) creating job opportunities for Saudis in the private sector. Saudi Arabia introduced a tax in July 2017, whereby expatriates have to pay SARI00 per month per dependent, including children and domestic staff. The fee was expected to raise SARl billion in 2017. These were some of the main fiscal reforms introduced by Saudi Arabia in 2017, alongside an excise tax on harmful products. This fee will rise by SAR100 per year from 2018 to 2020 and will mostly affect professional expatriates. Saudi Arabia also announced a levy on expatriate employees at companies from January 2018, where foreign labor is equal to or exceeds national employees. Again the fee will rise on an annual basis, though by SAR200 per year. The wage (and skills) gap between nationals and expatriates will likely not be bridged by this levy and thus will be an additional cost for companies to absorb (Table 10.3) (Figs. 10.11 and 10.12).

Oman: To support job creation for Omanis, a six-month ban on hiring expatriates began in January 2018 in 10 different industries, including media, information technology, marketing, insurance and aviation. The expatriate visa ban was extended for an additional six months at end-May, and extra sectors were added, including carpentry, metal, aluminium workshops and brick factories. The Omani government has also been looking to increase the number of nationals in the public sector. The visa ban was extended for a fourth time in mid-2019, again with four more 
Table 10.3 Schedule of fees and levies on expatriates

\begin{tabular}{|c|c|c|c|}
\hline & Dependents for Expats & $\begin{array}{l}\text { No. of Expats equal to no. of } \\
\text { Saudis in a company }\end{array}$ & $\begin{array}{l}\text { Expats more than Saudis } \\
\text { in a company }\end{array}$ \\
\hline 2017 & $\begin{array}{l}\text { SAR } 100 \text { per month from } \\
\text { July onwards }\end{array}$ & & \\
\hline 2018 & $\begin{array}{l}\text { SAR } 200 \text { per month from } \\
\text { July onwards }\end{array}$ & $\begin{array}{l}300 \text { per month from January } \\
\text { onwards }\end{array}$ & $\begin{array}{l}400 \text { per month from } \\
\text { January onwards }\end{array}$ \\
\hline 2019 & $\begin{array}{l}\text { SAR } 300 \text { per month from } \\
\text { July onwards }\end{array}$ & $\begin{array}{l}500 \text { per month from January } \\
\text { onwards }\end{array}$ & $\begin{array}{l}600 \text { per month from } \\
\text { January onwards }\end{array}$ \\
\hline 2020 & $\begin{array}{l}\text { SAR } 400 \text { per month from } \\
\text { July onwards }\end{array}$ & $\begin{array}{l}700 \text { per month from January } \\
\text { onwards }\end{array}$ & $\begin{array}{l}800 \text { per month from } \\
\text { January onwards }\end{array}$ \\
\hline
\end{tabular}

Source: Saudi Arabia Fiscal Balance Program 2020 (2016b, 51)

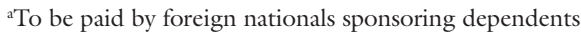

bfess on corporates

\section{Millions}

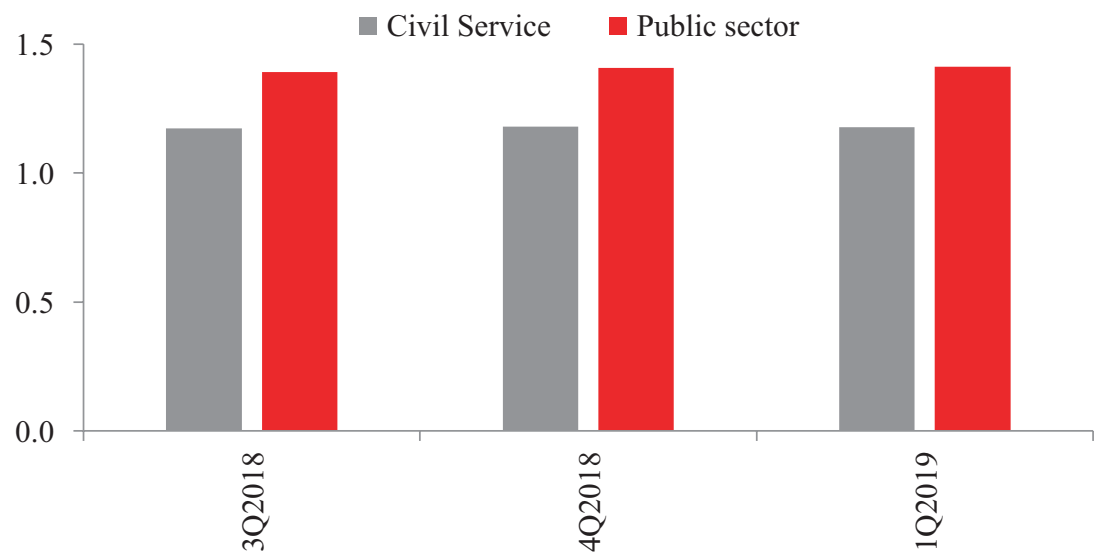

Fig. 10.11 Saudi: Public sector employment seen rising though civil services hiring remains broadly steady. (Source: Saudi Arabia General Authority for Statistics)

categories added. Omanization quotas have also been increased in certain sectors, including industry and tourism. On 3 October 2017, Oman announced that $25 \mathrm{~K}$ jobs would be created for nationals in both the private and public sectors starting from December. 


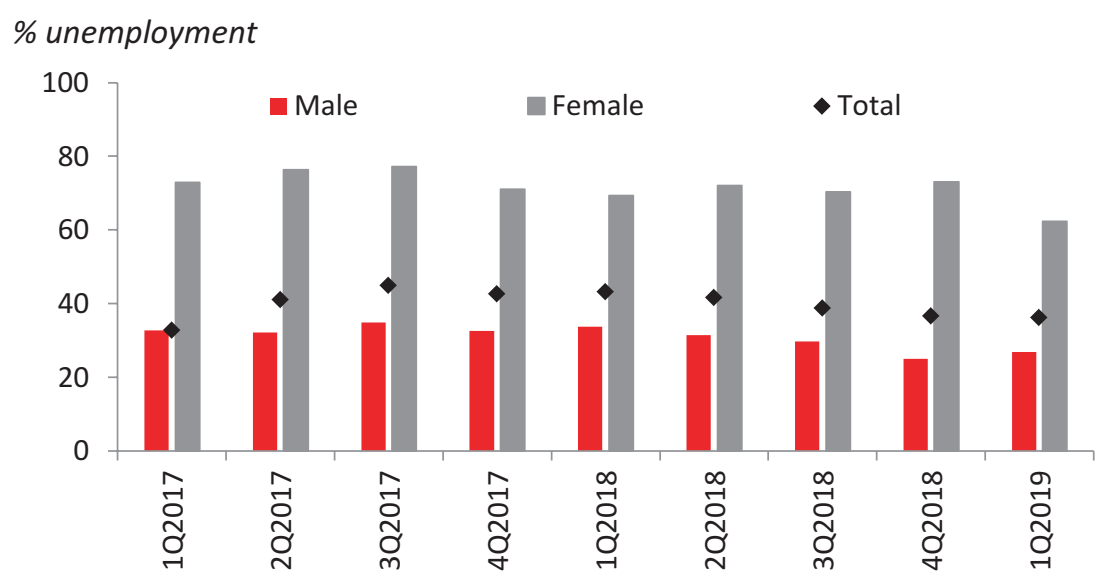

Fig. 10.12 Saudi: Unemployment rate amongst Saudi youth (20-24 years) high at $36.3 \%$ in 1Q2019. (Source: Saudi Arabia General Authority for Statistics)

Kuwait: Some resentment against the expatriate population has been visible in Kuwait, including among some MPs in the National Assembly looking to capitalize on growing resentment against non-nationals. MP Safa Al-Hashem was quoted as saying that "Before asking citizens to pay, the government should reform the population mix by levying taxes on foreigners" (Bloomberg 2017). The populist belief is that lowering expatriate numbers will help to reduce the subsidy burden. The government introduced a framework in 2017 to reduce the number of foreign workers in ministries and government institutions to create jobs for nationals. According to Kuwait Times, some 2799 expatriate jobs were terminated from the government sector in the first year of implementation of the Kuwaitization push to replace expat employees with nationals (Kuwait Times 2018). The government issued a decree to reduce the number of expatriates in all government departments by fiscal year 2019-2020 to reach a 90\% Kuwaitization rate (Arab Times). However, the president of the Civil Service Commission indicated that Kuwait is not in a position to replace all expatriates working in the public sector due to a shortage of potential Kuwaiti employees (Gulf News 2018). Meanwhile, a ban on recruiting expats under the age of 30 holding diplomas and higher degrees came into effect in July 2018 in an attempt to increase the hiring of younger Kuwaitis, though this has been currently postponed (Moody's 2019, 9). 
Elsewhere, Abu Dhabi also announced plans to create at least $10 \mathrm{~K}$ jobs for Emiratis in the private and public sectors over the next five years in June 2018, as part of a multi-year stimulus plan (Ghadan 21). Dubai's 2019 budget looks to create 2498 additional positions. In Bahrain, the cabinet approved hikes in fees imposed on foreign labor licenses under a job nationalization program to BHD500 (from BHD200) in February 2019 within the draft budget (Banker Middle East 2019). It also proposed higher unemployment benefits for Bahrainis. On the other side, a key component of Bahrain's Fiscal Balance Program is to introduce a voluntary retirement scheme to reduce government spending on wages. However, the progress with this is likely to be gradual.

GCC governments have also looked to progress with housing and education projects for nationals, alongside schemes to promote housing loans (via the government entities or in conjunction in the private sector). A number of housing projects have been announced in the UAE for nationals. In Saudi Arabia, an objective of Vision 2030 is to raise home ownership by nationals and a number of affordable housing programs have been introduced. In January 2018, SAMA raised the maximum loan-to-value rate for mortgages for first-time homebuyers to $90 \%$ from $85 \%$ in an effort to stimulate mortgage lending. Banks are also partnering with Real Estate Development Fund (REDF) to help develop the affordable housing segment, with the REDF providing support to eligible customers in the form of down payments, guarantees or full or partial payments on the interest on the mortgage.

\section{Pressure on Expatriate Population AND ECONOMIC IMPACT}

Oman and Saudi Arabia have particularly seen large declines in expatriate populations in the past few years. In the case of Saudi Arabia, the data points so far to a relatively limited number of jobs being created for nationals, especially given the magnitude in the contraction of expatriate employment. In the case of Oman, official statement indicates some positive trends in private-sector job creation, suggesting that there has been some success in Omani nationals replacing expatriates. However, a question remains over labor policy and the private sector's ability to expand and drive economic activity and create new jobs in the medium to longer term. Looking ahead, the hydrocarbon weaker per capita countries will continue 
to face the twin challenges of narrowing the fiscal deficit and ensuring that the economy creates sufficient job opportunities for the youth.

The expatriate labor force in Saudi Arabia declined in 2017 and 2018 with the dependent's fee, corporate levy on expatriate labor and rising Saudiization requirement. Nevertheless, as noted earlier, the unemployment rate for Saudi nationals has remained high. Around 1.53 million expatriates left the labor market in 2017 and 2018 combined, whilst the number of Saudis employed in the private sector rose by just $52.9 \mathrm{~K}$ over the same period. The rise in expatriates jobs in 1Q2019 by some $223.8 \mathrm{~K}$ to 9.65 million was solely driven by domestic workers, with foreign labor working in the private and government sectors continuing to decline (ADCB 2019, 1). The fact that expatriate workers are not always being replaced by nationals partly reflects the skills mismatch among domestic workers and the higher costs of national labor (ADCB 2018, 7). However, there are signs of a rise in public sector employment of Saudis from 3Q2018 to 1Q2019 (period data available) (Figs. 10.13 and 10.14).

In Oman, official statement indicated that 64,386 jobs were created for Omanis in the private sector in 2018 amid the expatriate visa ban. Meanwhile, official data show that a total of $67.4 \mathrm{~K}$ expatriates left the

'000, change in total number of people employed

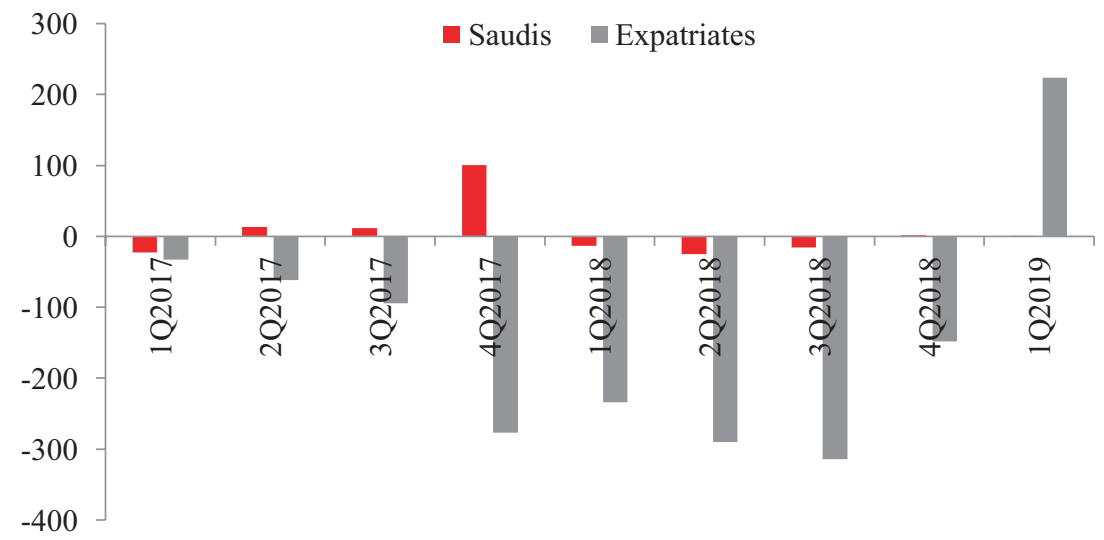

Fig. 10.13 Saudi Arabia: Saudi nationals largely not replacing expatriate jobs lost. (Source: Calculated from Saudi Arabia General Authority for Statistics data) 


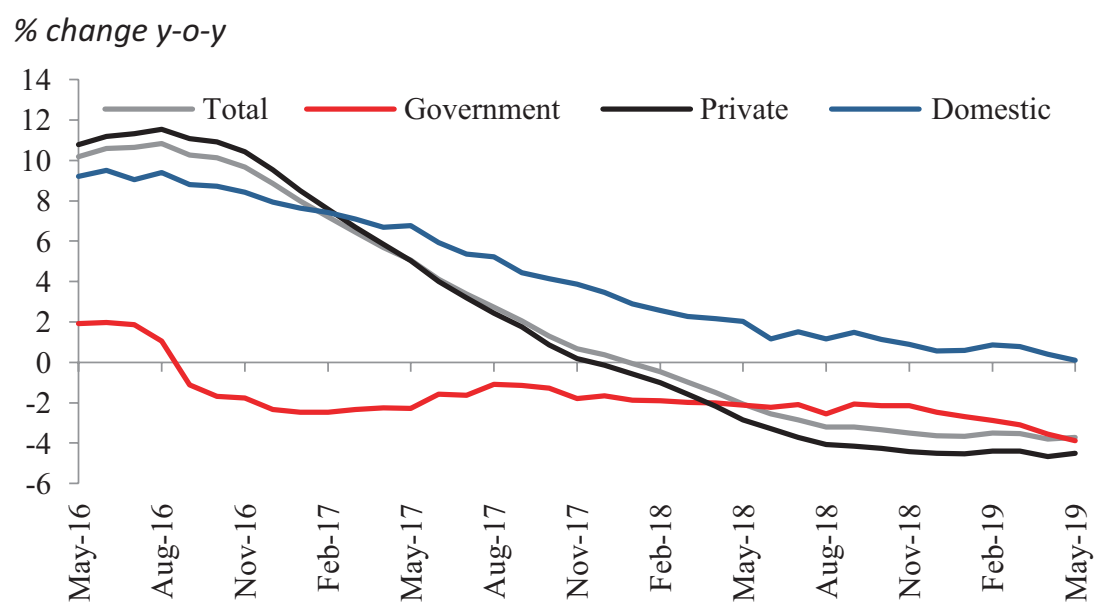

Fig. 10.14 Oman: Expatriate labor force contracted in 2018 with visa ban on a number of sectors. (Source: Calculated from Oman's Ministry of National Economy data)

private labor force in 2018, indicating that Omani nationals have largely been replacing expatriates in this year. The latest data continues to point to a further decline in the expatriate labor force in 2019, contracting by $3.7 \%$ y-o-y in May (public sector: $-3.9 \%$; private sector: $-4.5 \%$ ). The sector seeing the greatest fall in 5M2019 was construction, alongside mining, utilities, transport and storage and financial.

Any moderation in the unemployment rate among nationals will be positive for the consumption outlook, especially given the propensity to save and the high level of remittances associated with expatriate labor. However, in the more immediate term, the fall in the expatriate population is contributing to weakness in private consumption. Moreover, the fall in expatriate workers in Saudi Arabia, Oman and Kuwait is resulting in a fall in rental prices, quite marked in some areas. The IIF noted that the "Weakness in the real estate market has both reflected and contributed to weak economic growth in much of the GCC" $(2019,1)$. Investment in the real estate sector is popular with nationals; the fall in population and rental prices is impacting income of individuals and, in some cases, corporates. The Times of Oman indicated that some areas of Muscat were seeing rental drops as much as $40-60 \%$, with indications of vacant properties in both Kuwait City and Muscat (Kuwait Times 2019, Times of Oman 
2019). In the UAE and Qatar, the lack of private sector job growth has also contributed to the fall in rental prices, though the sharp rise in supply has also been a key factor. GRE restructuring has largely been aimed at extracting cost efficiencies, though it has also resulted in labor market weakness and job losses largely of expatriates.

More detrimental to regional economies would be a skills shortage and/ or a moderation in productivity. Indeed, in Oman and Saudi Arabia, who have particularly seen a significant loss in expatriate labor, there have been indications that the private sector has faced rising costs from this-including having to find replacement labor, skills mismatches and the generally higher cost of national labor versus expatriate labor. In Saudi Arabia, in sectors seeing 100\% Saudiization, a number of companies have gone out of business, especially SMEs, given the higher cost of hiring nationals. In Saudi Arabia, the average wage per month of an expatriate working in the private sector was around SAR4060 in 1Q2019 and SAR7099 for a national. Around 3000 mobile phone retailers closed down following the $100 \%$ nationalization of labor in this sector in September 2016 (EFG Hermes 2018, 10). The introduction of a fee on expatriate labor in January 2018 in Saudi Arabia is an extra burden (Saudi Gazette, 14 February 2018). The pressure on corporates has been compounded by a shift in the payment system, from an annual work permit renewal to a one-time lump-sum payment at the beginning of the year for all foreign workers employed-that is, collective invoicing. The loss of jobs in the private sector is reducing its productive capacity and further suppressing household demand, at a time of either fiscal austerity or weak government spending growth. Private sector companies have had to discount prices to support sales, thus adding additional pressure on margins, alongside the rise in costs of labor.

Recognizing that the increase in expatriate labor costs has been one of the many challenges facing the private sector, there have been some adjustments to the plan to reduce the impact on corporates. Businesses with fewer than nine employees are exempt from the expatriate levy for their first five foreign workers. Moreover, in early 2019, the government announced a scheme to reimburse some firms for the rising cost of expatriate labor fees, with SAR11.5 billion (USD3.1 billion) being allocated. However, the payment mechanism and eligibility criteria will be central in our view. The decree indicates that the scheme will only be available to companies with a higher or equal number of Saudi employees versus expatriates. Thus, a number of labor-intensive sectors that are struggling to attract Saudi employees or are impacted by the higher cost of Saudi labor might see limited benefits. 


\section{Conclusion}

Reducing the wage composition of government spending will be critical to boosting fiscal sustainability across the GCC, especially for the hydrocarbon poorer per capita countries, and reducing their budget breakeven oil process. Raising the skills set of the population and human capital to meet the need of the private sector will be important for reducing dependence on government employment. This process will take time and is required at all educational levels, though it will still have to adapt to changing landscapes, including technological advancements and digital transformation. Factors such as labor market dynamics, productivity levels and mismatch in worker skills have also impeded FDI into the region, alongside private sector development. Without upgrading the human capital base of the economies, there is a risk that investment will mostly be on infrastructure without developing or attracting businesses and resulting in job creation. Better aligning the benefits (salaries, holidays, etc.) of the public in line with the private sector should also reduce the demand of working for the government. The youth population in GCC countries tends to be high, thus the employment demand is expected to rise, especially in Oman and Saudi Arabia. Creating private sector jobs will be central for reducing the reliance on the state for employment, which in turn will allow a greater scope for reducing wage spending.

Providing institutional support to the private sector during the transition period will also be important. Non-oil activity has remained weak across the GCC with the fiscal austerity of the last few years. Even though the pace of fiscal reforms has slowed and there has been a shift to expansionary government spending from 2018 , oil prices have not recovered to a point for governments to provide a meaningful stimulus. The private sector is expected to provide jobs, new jobs at a time of weak economic activity and growth and, in some cases, with or after rising cost of doing business including labor. As noted, in the case of Saudi Arabia, the marked drop in the expatriate labor force, which is not being replaced by nationals, is resulting in an erosion of the production base. The private sector in the regions has traditionally relied on cheap foreign labor, and has arguably also been a part of the social contract, and had to also adjust. As we noted in our earlier chapter, the UAE has introduced a number of measures to support the private sector, including reduction in fees and regulatory reforms. This is supported by its stronger fiscal position in the region. However, other countries are not in a position to do this and still have 
significant fiscal reforms to introduce. Developing further training and apprentice schemes between the government and the private sector could be a way to complement educational reforms, support job creation and help reduce the burden on the private sector until workers reach the skill requirement.

Thus, the development of a framework to boost private sector activity, including through PPP schemes, remains vital. Moreover, in Saudi Arabia, the Public Investment Fund (PIF) is playing a central role in the transformation plans and the development of new industries (tourism, finance, industrial, etc.). This includes leading the development of major projects (such as NEOM, Al-Ula and Amaala) and the redevelopment of cities such as Jeddah and Medina. The development of these new sectors and the role of the PIF could potentially create or define a new private sector with a different relationship with the state, albeit still connected. The inclusion of the current private sector in these developments and projects will also be critical on how it develops and their role in creating new jobs. Looking forward, with increased globalization and for expanding the nonhydrocarbon and petrochemical export base, the domestic labor force will have to compete internationally on cost and productivity. This will especially be the case for the relatively hydrocarbon weaker per capita countries, where their economies will depend more on domestic labor. Any higher cost of labor will have to be supported by productivity gains. This level of productivity, alongside the sectors that will drive diversification away from hydrocarbons, has further significance for the level of wages and spending capacity of household, as the private sector will increasingly have to play a greater role in job creation. If the private sector does not provide adequate employment opportunities, then benefit payments and/ or public sector wage would have to increase further.

\section{REFERENCES}

ADCB Economic Research. 2017a. GCC Economic Update: Higher oil prices to provide some relief, though growth recovery to be weak (Published on 16 February 2017, authors Monica Malik and Shailesh Jha)

ADCB Economic Research. 2017b. Saudi Arabia Economic Update-Winds of change. (Published on 16 November 2017, authors Monica Malik and Thirumalai Nagesh). 
ADCB Economic Research. 2018. Saudi Arabia Economic Update-Weather watching as winds change (Published 9 December 2018), authors Monica Malik and Thirumalai Nagesh).

ADCB Economic Research. 2019. Saudi Arabia Economic Update-Gradual fall in $1 Q$ national unemployment rate; challenges remain (Published 11 June 2019), authors Monica Malik and Thirumalai Nagesh).

Albawaba. 2018. 70 Percent Saudization in These 12 Sectors (published on 29 August 2018) https://www.albawaba.com/business/ 70-percent-saudization-these-12-sectors-1178800.

Banker Middle East. 2019. Bahrain projects \$1.6 billion budget deficit in 2020. (Published on 26 February 2019) https://www.bankerme.net/en/home/ articles/bahrain-projects-1.6-billion-budget-deficit-in-2020.html?\% 3Fcountry-tag=.

Bloomberg. 2017. In One of the World's Richest Nations, Anti-Immigrant Tide is Rising (published 13 April 2017, author Zainab Fattah).

EFG Hermes Equity Research. 2018. Saudi Consumer and Retail-Eyes on retail consolidation plays, some food names offer good value but lack catalysts. (Published on 31 May 2018, authors Hatem Alaa, et al).

Gulf News. 2018. Replacing public sector expats 'too difficult'. (Published 20 May 2018) https://gulfnews.com/world/gulf/kuwait/replacing-publicsector-expats-too-difficult-1.2224119.

IMF. 2018. Regional Economic Outlook Middle East, North Africa, Afghanistan, and Pakistan. (Published May 2018) https://www.imf.org/en/ Publications/ /media/E7F9D70809DF4lA8A55D8046Al3480F0.ashx.

Kingdom of Saudi Arabia. 2016b. Fiscal Balance Program, Balanced Budget 2020. https://vision2030.gov.sa/en/bb2020.

Kuwait Times. 2018. 2,799 expatriates terminated in first year of replacement plan. (Published on 22 December 2018) https://news.kuwaittimes.net/ website/2799-expatriates-terminated-in-first-year-of-replacement-plan/.

Kuwait Times. 2019. Apartments vacant as expatriates leave Kuwait amid. (Published on 4 July 2019) https://news.kuwaittimes.net/website/ apartments-vacant-as-expatriates-leave-kuwait-amid-hardship/.

Moody's Investors Service. 2019. 2019 outlook is stable, but fiscal reform, geopolitics and unemployment pose challenges. (Published on 16 January 2019, authors Thaddeus Best, Alexander Perjessy, et al.).

Times of Oman. 2019. 65,000 expats left Oman in a year (published on 16 July 2019). https://timesofoman.com/article/1617683.

World Bank: Oman's Economic Outlook. 16 April 2018; https://www.worldbank.org/en/country/gcc/publication/economic-outlook-april-2018-oman. 
Open Access This chapter is licensed under the terms of the Creative Commons Attribution-NonCommercial-NoDerivatives 4.0 International License (http:// creativecommons.org/licenses/by-nc-nd/4.0/), which permits any noncommercial use, sharing, distribution and reproduction in any medium or format, as long as you give appropriate credit to the original author(s) and the source, provide a link to the Creative Commons license and indicate if you modified the licensed material. You do not have permission under this license to share adapted material derived from this chapter or parts of it.

The images or other third party material in this chapter are included in the chapter's Creative Commons license, unless indicated otherwise in a credit line to the material. If material is not included in the chapter's Creative Commons license and your intended use is not permitted by statutory regulation or exceeds the permitted use, you will need to obtain permission directly from the copyright holder. 